\title{
Molecular profiling of an osseous metastasis in glioblastoma during checkpoint inhibition: potential mechanisms of immune escape
}

Malte Mohme ${ }^{1 *}$, Cecile L. Maire ${ }^{1}$, Simon Schliffke ${ }^{2}$, Simon A. Joosse ${ }^{3}$, Malik Alawi $^{4}$, Jakob Matschke ${ }^{5}$, Ulrich Schüller ${ }^{5,6,7}$, Judith Dierlamm² ${ }^{2}$ Tobias Martens ${ }^{1}$, Klaus Pantel ${ }^{3}$, Sabine Riethdorf ${ }^{3}$, Katrin Lamszus ${ }^{1}$ and Manfred Westphal ${ }^{1 *}$

\begin{abstract}
Peripheral metastases of glioblastoma (GBM) are very rare despite the ability of GBM cells to pass through the blood-brain barrier and be disseminated through the peripheral blood. Here, we describe a detailed genetic and immunological characterization of a GBM metastasis in the skeleton, which occurred during anti-PD-1 immune checkpoint therapy. We performed whole genome sequencing (WGS) and $850 \mathrm{~K}$ methylation profiling of the primary and recurrent intracranial GBM as well as one of the bone metastases. Copy number alterations (CNA) and mutational profiles were compared to known genomic alterations in the TCGA data base. In addition, immunophenotyping of the peripheral blood was performed. The patient who was primarily diagnosed with IDHwildtype GBM. After the resection of the first recurrence, progressive intracranial re-growth was again detected, and chemotherapy was replaced by PD-1 checkpoint inhibition, which led to a complete intracranial remission. Two months later MR-imaging revealed multiple osseous lesions. Biopsy confirmed the GBM origin of the skeleton metastases. Immunophenotyping reflected the effective activation of a peripheral T-cell response, with, however, increase of regulatory $T$ cells during disease progression. WGS sequencing demonstrated distinct genomic alterations of the GBM metastasis, with gains along chromosomes 3 and 9 and losses along chromosome 4, 10, and 11. Mutational analysis showed mutations in potentially immunologically relevant regions. Additionally, we correlated tumour-infiltrating lymphocyte and microglia presence to the occurrence of circulating tumour cells (CTCS) in a larger cohort and found a decreased infiltration of cytotoxic T cells in patients positive for CTCs. This study exemplifies that the tumour microenvironment may dictate the response to immune checkpoint therapy. In addition, our study highlights the fact that despite an effective control of intracranial GBM, certain tumour clones have the ability to evade the tumour-specific T-cell response and cause progression even outside of the CNS.
\end{abstract}

Keywords: Glioblastoma, Metastasis, T-cells, Tumour-infiltrating lymphocytes, Immune escape, Whole genome sequencing, Circulating tumour cells

* Correspondence: m.mohme@uke.de; westphal@uke.de 'Department of Neurosurgery, University Medical Center Hamburg-Eppendorf, Martinistr. 52, 20246 Hamburg, Germany

Full list of author information is available at the end of the article

(c) The Author(s). 2020 Open Access This article is licensed under a Creative Commons Attribution 4.0 International License, which permits use, sharing, adaptation, distribution and reproduction in any medium or format, as long as you give appropriate credit to the original author(s) and the source, provide a link to the Creative Commons licence, and indicate if changes were made. The images or other third party material in this article are included in the article's Creative Commons licence, unless indicated otherwise in a credit line to the material. If material is not included in the article's Creative Commons licence and your intended use is not permitted by statutory regulation or exceeds the permitted use, you will need to obtain permission directly from the copyright holder. To view a copy of this licence, visit http://creativecommons.org/licenses/by/4.0/ The Creative Commons Public Domain Dedication waiver (http://creativecommons.org/publicdomain/zero/1.0/) applies to the data made available in this article, unless otherwise stated in a credit line to the data. 


\section{Introduction}

Metastatic dissemination of glioblastoma (GBM) is rare. Less than $0.5 \%$ of patients develop extracranial GBM tumour manifestation [12, 20, 31, 32]. Multiple hypotheses have been postulated why, this otherwise so aggressively growing tumour, only rarely forms metastases outside the brain. The commonly discussed pathophysiological ideas are the "seed vs soil" hypothesis [16, 29], which describes the inability of cells to adapt and home to the tissue microenvironment outside the brain, and the "peripheral immunosurveillance" hypothesis, which holds that the activated peripheral immune system is able to eliminate GBM tumour cells that left the immune protected brain microenvironment.

The discovery of circulating tumour cells (CTCs) in GBM has renewed the interest in this discussion. In one of the first studies of its kind, Müller et al. detected CTCs in up to $20 \%$ of patients [31]. Cells in the peripheral blood were identified by their expression of the astrocytic marker GFAP. Further studies incorporating additional CTC isolation techniques consecutively found circulating GBM cells in up to $39 \%$ of patients, with a preferential enrichment of CTCs in GBM displaying a mesenchymal gene expression profile $[24,39]$. It remains unclear, however, why the CTCs do not form extracranial tumours at the expected frequency. The occurrence of extracranial GBM metastases in patients receiving organ donations from GBM patients points to a decisive role of the immune system in containing extracranial growth [19].

GBM metastases have been described to occur at various sites, including bone, lymph nodes, lung and liver, but also to the skin, thus in part challenging the "seed vs soil" hypothesis [14, 15, 17, 34, 41]. In the context of ongoing trials to study the efficacy of immunotherapy for GBM, recent studies focused on the immunosuppressive capacities of GBM in the brain microenvironment as well as its immunomodulation of the peripheral immune surveillance $[5,9$, 30]. These studies revealed a strong interaction of the intracranial tumours with the peripheral immune system and demonstrated that immune escape of GBM is not limited to the local tumour environment, but also impacts the peripheral immune system. These observations emphasize the importance to study immune escape mechanisms in rare cases of extracranial GBM metastasis.

In the here presented case, we illustrate the immunological escape of a peripheral GBM metastasis, which formed during intracerebral tumour control with checkpoint inhibition. The molecular and immunological profiling presented in this study provides new insights into potential mechanisms of immune escape and metastatic tumour evolution.

\section{Case presentation}

A 74-year-old male patient initially presented with dysphasia, vertigo and fatigue. Cranial MR imaging revealed a large contrast-enhancing inhomogeneous mass in the right temporal lobe (Fig. 1). Surgical resection and subsequent histological analysis and methylation array analysis confirmed the presence of an IDH1-wildtype GBM WHO ${ }^{\circ} \mathrm{IV}$ with methylated MGMT gene promoter and mesenchymal subtype. Standard adjuvant therapy with combined radio-chemotherapy with temozolomide and $30 \times 2$ Gy was initiated (Fig. 1). In week 37 a recurrence was detected (Fig. 2). Second resection confirmed active tumour recurrence with strong PD-L1 expression (30\%) (Fig. 3). The interdisciplinary tumour board recommended intensified temozolomide therapy. Shortly after initiation of the chemotherapy, large radiographic progression was detected (Fig. 2). Given the fast progression, high PD-L1 expression in the recurrent tumour (Fig. 3), and the at the time ongoing phase-III nivolumab trials, [33] anti-PD1 checkpoint inhibition with nivolumab was initiated. Within 4 weeks the contrastenhancing lesion increased (Fig. 2). Due to a stable clinical appearance of the ambulatory patient, nivolumab treatment was continued. Short term MR imaging then showed an almost complete remission of the intraparenchymal contrast enhancing lesion, which was suspected as immunological flare up and response to checkpoint inhibition (Fig. 2b). Unfortunately, 6 weeks later the patient came back with severe back pain. Whole-spine imaging demonstrated multiple intraosseous enhancing lesions in vertebral bodies C7, Th2, - 9 and L3. Needle biopsy of L3 and interdisciplinary pathological evaluation, together with the presence of GFAP positive cells and the absence of epithelial (e.g. AE1/3, EMA) and melanocytic (e.g. S100, HMB45, Melan-A) markers confirmed metastatic dissemination of the intracerebrally controlled GBM (Fig. 3). The Ki67-labeling index was positive in $10-15 \%$ of cells. Spiral computer tomography (CT) of the thorax and abdomen did not show other masses suspicious for another cancer entity. Nivolumab treatment was stopped and radiotherapy of the spinal tumours combined with anti-angiogenic treatment using bevacizumab was started (Fig. 1). Throughout the radiotherapy the patient further progressed, and the general health condition decreased. In the palliative context, treatment was discontinued, and the patient died 28 months after the initial diagnosis.

Given the unique pattern of intracranial remission during checkpoint inhibition and the simultaneous metastatic peripheral osseous dissemination, further immunological and genomic profiling was performed. Phenotyping of the peripheral blood immune subpopulations at the time of initial tumour resection, tumour recurrence, metastatic presentation and during further 


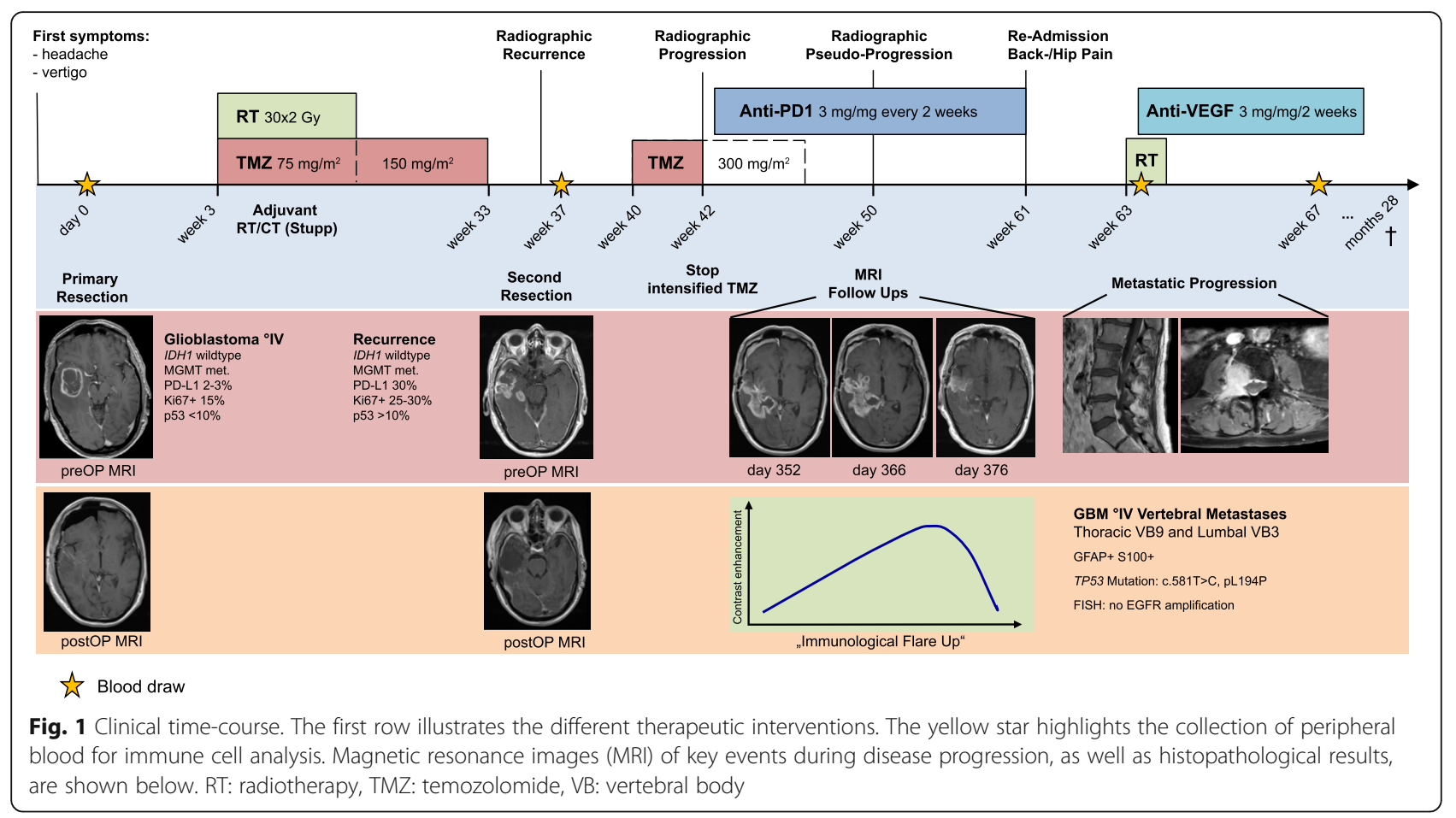

adjuvant therapy revealed a steady increase in the $\mathrm{T}$ cell population. This increase was dominated by a $\mathrm{CD} 8^{+}-$ and NK $\mathrm{T}$ cell peak during the first intracerebral tumour recurrence, while regulatory $\mathrm{T}$ cells dropped continuously until occurrence of metastases before again increasing in the final disease stage (Fig. 4a). $\mathrm{CD} 8^{+} \mathrm{T}$ cell activation, as reflected by CD25 surface marker expression, declined until radiotherapy of the vertebral body metastases was performed (Fig. 4b). Whereas the expression, or more likely detectability, of the immune checkpoint marker PD-1 significantly dropped after nivolumab treatment was started, the expression of other immune checkpoint molecules, such as KLRG1, CD57 and Tim-3 increased until peripheral metastasis occurred. After radiotherapy of the spinal metastases and during anti-angiogenic treatment, their expression again decreased (Fig. 4c). The increase of "exhaustion" markers, which are expressed during the process of $\mathrm{T}$ cell activation before metastasis, was accompanied by an increase in the $\mathrm{CD}^{+}$terminal effector (Tte) $\mathrm{T}$ cell compartment (Fig. 4c, d), which describes a memory $\mathrm{T}$ cell population with a potentially strong cytolytic function, but limited anti-cancer efficacy due to its inability to self-renew [2]. The $\mathrm{CD} 4^{+} \mathrm{T}$ cell differentiation remained rather stable at all four time-points.

In order to investigate if the patient had peripherally circulating tumour cells (CTCs), we screened the blood of the patients at multiple time points using GFAP immunostainings to identify CTCs, as previously published [31]. In addition, given the p53 mutation in the peripheral metastasis, we also performed p53 immunostainings. No CTCs could be detected at any given timepoint in this patient, not even in the metastatic state.

However, to analyse if the presence of CTCs in general could be correlated with the amount of tumourinfiltrating $\mathrm{T}$ cells and intratumoural microglia, we immunohistochemically stained the tumours of the previously published cohort for CD3, CD8 and CD68 ( $n=$ 116, Fig. 5) [31]. Here, the presence of peripheral CTCs $(\mathrm{CTC}+)$ correlated with low intratumoural $\mathrm{T}$ cells $\left(\mathrm{CD}^{+}, p=0.001, t\right.$-test) and low cytotoxic $\mathrm{T}$ cells $\left(\mathrm{CD}^{+}, p=0.014, t\right.$-test), while no difference for $\mathrm{CD} 68^{+}$ macrophages/microglia was observed (Fig. 5c). This observation highlights the potential link between the tumour-specific immunocompetence and the occurrence of peripheral CTCs.

Next, we were able to isolate genomic DNA from the metastasis biopsy and perform whole genome sequencing (WGS) and $850 \mathrm{~K}$ methylation profiling in all three tumour samples. Global genomic methylome confirmed the diagnosis of MGMT-methylated $I D H$-wildtype GBM ${ }^{\circ} \mathrm{IV}$ in all three specimens (calibrated scores: primary GBM: 99, recurrence GBM: 98, metastasis: 89). Copy number alterations (CNA) extracted from the methylation profiling confirmed the WGS analysis with clear amplification of chromosome 7 and deletion of $C D K N 2 A$ in all 3 specimens which are genomic alterations characteristic of GBM (Fig. 6a). However, while the primary and recurrent GBM were grouped into the mesenchymal subtype, the metastasis could not clearly 


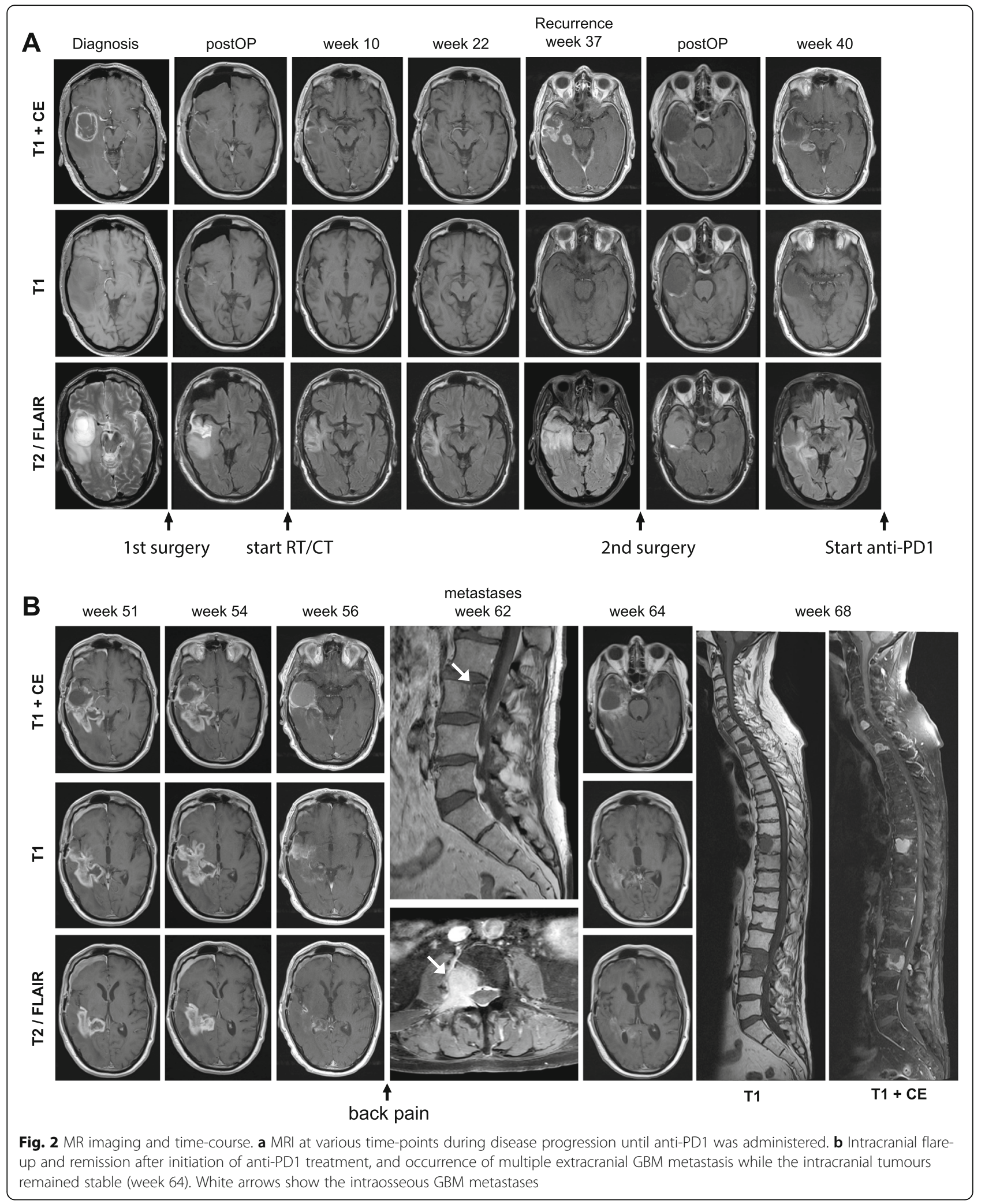



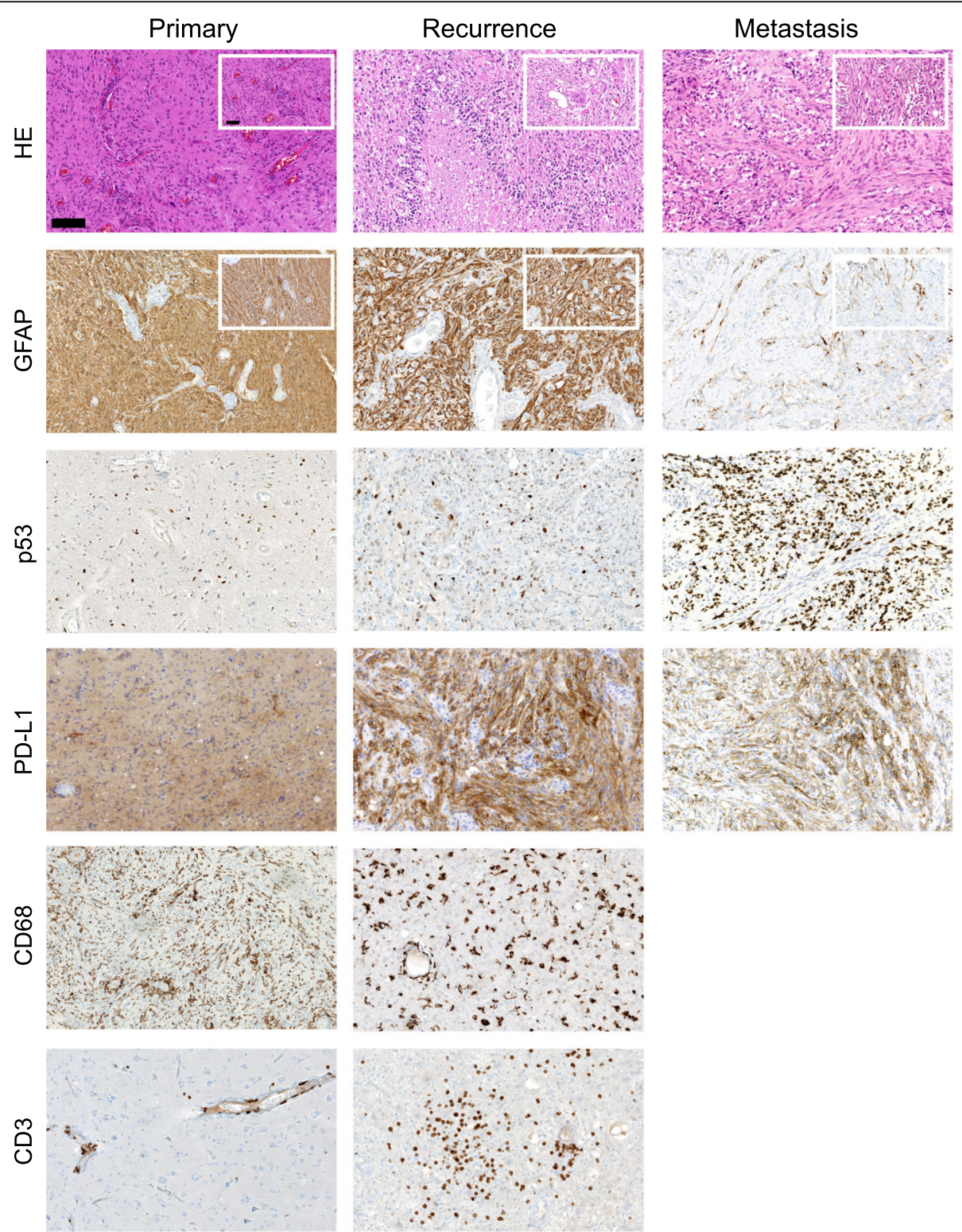

Fig. 3 Histological and immunohistochemical analyses. Staining for hematoxylin \& eosin (HE), p53, glial fibrillary acidic protein (GFAP), PD-L1, CD68 (microglia) and CD3 (pan T cell) of the initially diagnosed GBM (primary), its first intracranial recurrence (recurrence) and the biopsy specimen of the vertebral body metastasis from L3 (metastasis). Scale bars indicate $100 \mu \mathrm{m}$ in larger images and $50 \mu \mathrm{m}$ in insets

be assigned to the mesenchymal (score 47) or RTK II (score 39) subtype, which is reflected in the t-SNE analysis (Fig. 6b).

WGS analysis also confirmed the GBM origin of the vertebral metastasis, with the CNA profile showing distinct gains in chromosome 7 and losses in parts of chromosome 5 and 9, which were shared between all three tumours (Suppl. Fig. 1). The OncoPrint representation, comparing mutations between all three tumours, shows 32 genes which have been selected if the gene is affected in at least two samples or if it has at least one variant with a COSMIC ID (Fig. 6c, Supplemental Table
1). As the metastasis shares two exclusive mutations with the primary cerebral GBM, we hypothesize that the metastasis clonally derived closer from the primary GBM, rather than from the recurrent GBM (Fig. 6d). However, the exact timing of metastatic manifestation cannot be determined. Mutations in TPDF52L3 and HIVEP2 were shared between all three tumours. HIVEP2, also known as MIBP2 (c-myc intron binding protein 1), was not only described to control the expression of multiple genes, many of which are involved in brain development, but also to inhibit glioma growth [38, 40]. A missense mutation might therefore be a 


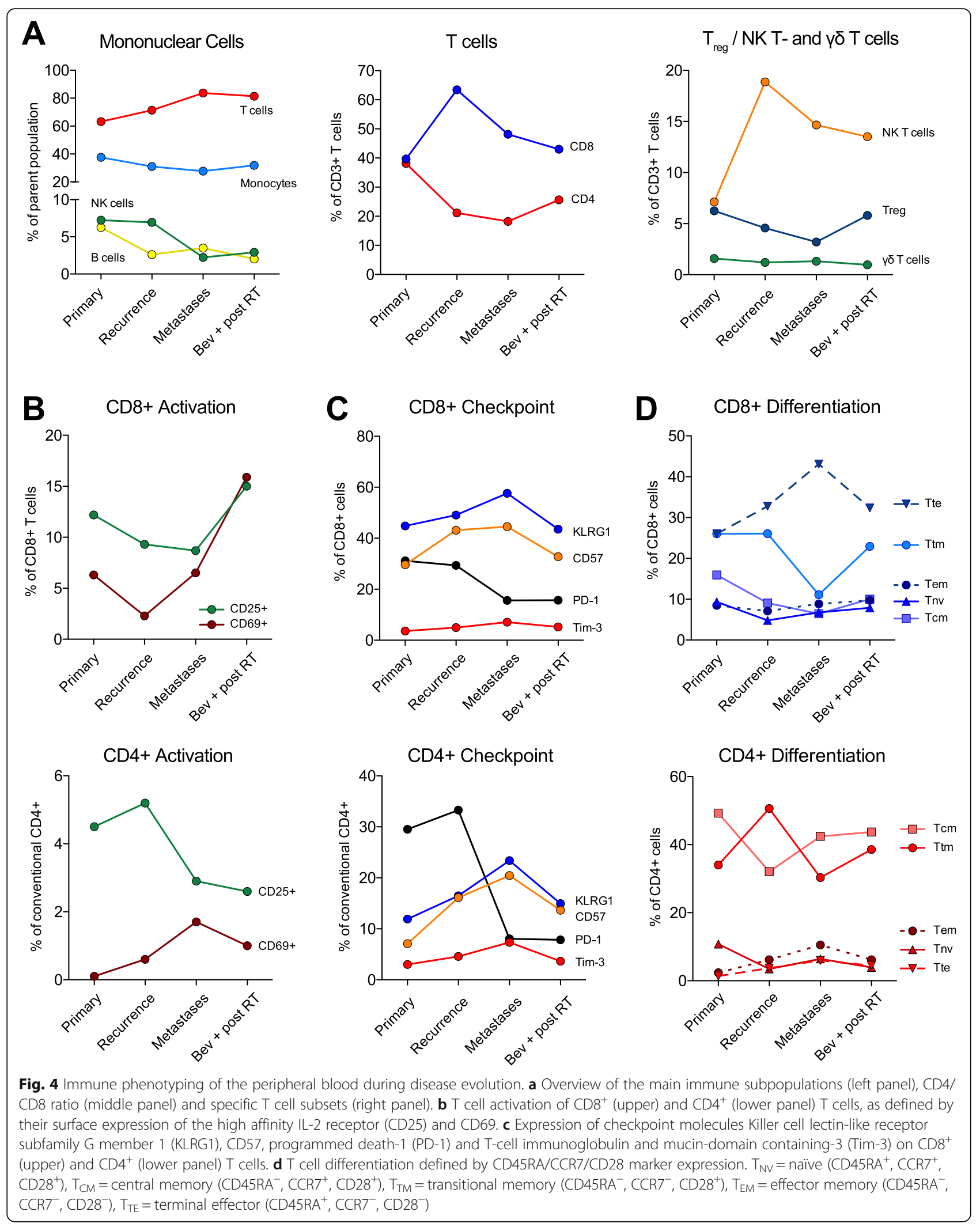




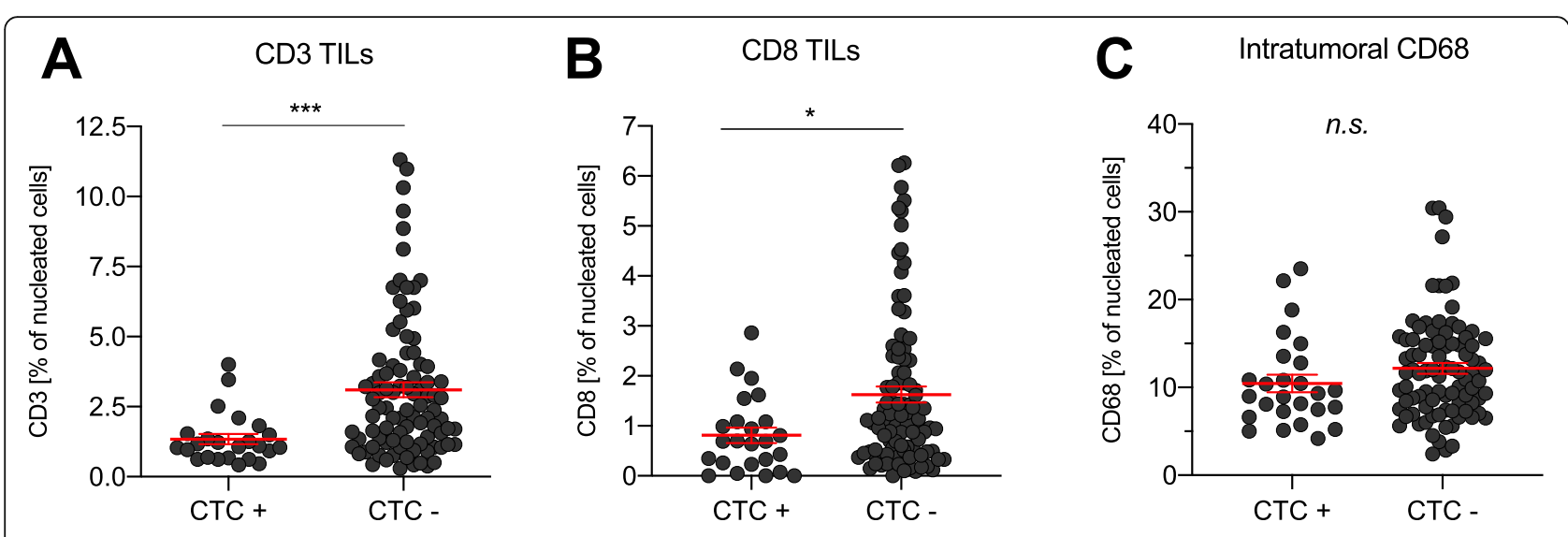

Fig. 5 Circulating tumour cell (CTC) count correlation to immunohistochemically quantified tumour-infiltrating immune cells. Presence of tumourinfiltrating lymphocytes (TIL), as automatically quantified by \% of nucleated cells was performed for CD3 ${ }^{+}$(a) and CD8 ${ }^{+} \mathrm{T}$ cells (b), as well as for $\mathrm{CD} 8^{+}$microglia and correlated to the presence of GFAP ${ }^{+}$peripheral circulating tumour cells, as defined in a previously published cohort [31].

common contributor to tumour development in this case. The following alterations characteristic for GBM were detected when applying a less strict threshold for analysis: PIK3CA p.E453Q (COSMIC ID: COSM758), NF1 p.I1679_Y1680del (COSMIC ID: COSM6969872) and $C D K N 2 A / \mathrm{B}(\mathrm{p} 15 / 16)$ deletion, further confirming the GBM origin of the metastasis. Additionally, a new mutation was found only in the metastasis in TP53 c.581 T > C p.L194P (COSMIC ID: COSM437527) by sanger sequencing during the initial pathological workup, which could be a possible key driver for tumour formation under anti-PD1 treatment. Among others, the metastasis harboured missense variant mutations in immunologically active genes, such as ANXA5, LGALS14 and FGL1 (Fig. 6a). These mutations have a potential impact on the immune recognition of tumour cells.

While the primary (0.42 mutations per $\mathrm{Mbp})$ and the recurrent ( 0.60 mutations per $\mathrm{Mbp}$ ) cerebral tumours, as expected for GBM, displayed low tumour mutational burden (TMB), the vertebral metastasis exhibited a 6.5times higher mutational burden (3.26 mutations per Mbp) (Fig. 6a, right panel), which is reflected in the greater amount of mutational variants affecting protein coding regions with known COSMIC mutations (Fig. 6d, left Venn diagram, COSMIC mutations only). Overall 28 mutations are found in the primary tumour, of which 14 were also present in the recurrent cerebral tumour, which presented with five new mutations (Fig. 6d, right Venn diagram, all non-silent mutations). The mutational profile was comparable in all the tumours, as they all show a $\mathrm{C}$ to $\mathrm{T}$ mutational profile characteristic for a COSMIC signature 1 (Fig. 6e) [13].

\section{Discussion and conclusion}

Our study shows a unique case of extracranial metastases from GBM during immunological remission of the intracerebral tumour with checkpoint inhibition. In order to form extracranial metastases, the tumour had to, either gain new genetic drivers to promote peripheral metastatic seeding, or suppress the peripheral immunosurveillance, or develop new mechanisms to evade from immune recognition during its metastatic spread, or both. Multiple case reports of GBM metastases have focused on genetic aberrations, potentially involved in tumour cell manifestation outside the brain [11, 43, 45]. Among others, alterations, such as BRCA1 and ARID1A mutations or overexpression of IGFBP2 have been described in these cases [44, 45]. Although we cannot exactly define when the metastatic seeding in our case occurred or if it is directly linked to anti-PD1 treatment, the tumour became symptomatic and most likely progressed during intracranial remission under immune checkpoint inhibition. We therefore decided to focus our discussion on potential immunological mechanisms.

Recent findings by Congsathidkieth et al. describe that intracranial GBM is able to suppress the peripheral immune response by sequestration of lymphocytes in the bone marrow via a S1P1-mediated mechanism [9]. While this type of immunomodulation might reflect an extension of the unique immunosuppressive intracranial environment in GBM, we do not have strong evidence for this particular phenomenon in the here presented case, as no significant lymphopenia was observed. We rather saw an increase of exhaustion or functional impairment in the $\mathrm{T}$ cell compartment, as demonstrated by the increased expression of other checkpoint molecules such as KLRG1, CD57, and Tim-3. This increase might be a result of compensatory mechanisms during PD-1 checkpoint blockade. Similar observations of a compensatory increase or adaptive resistance to PD-1 blockade by upregulation of additional checkpoints was described in mouse model for lung cancer [22]. The observed 


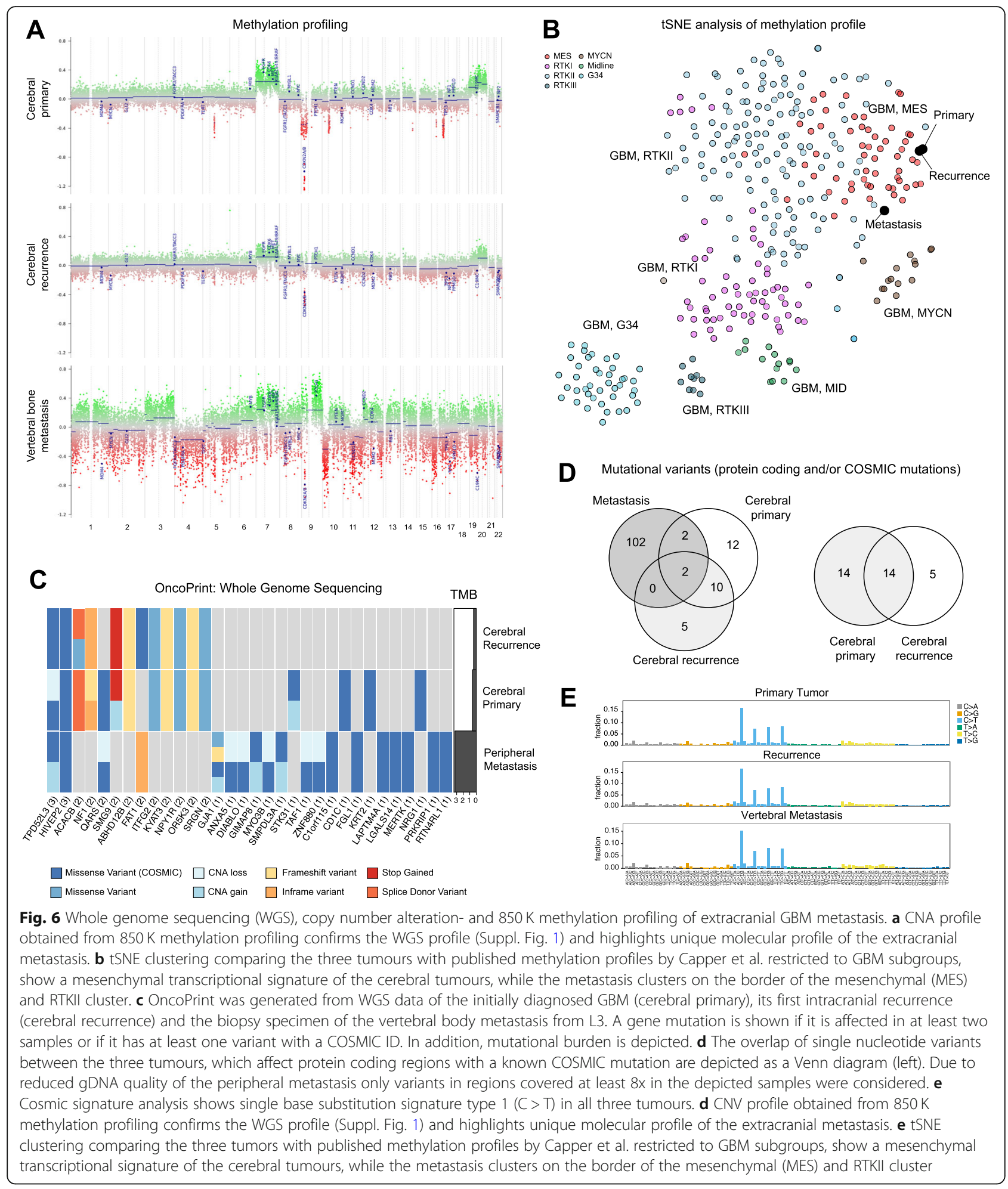

increase in terminal effector memory $\mathrm{CD}^{+} \mathrm{T}$ cells and decrease in the expression of the high affinity IL2R (CD25) further supports the hypothesis that peripheral immunosurveillance was functionally compromised during the metastatic spread of GBM cells.
Potentially relevant is also a recent study by Jiao et al., that demonstrated that the microenvironment of certain organs determines distinct mechanisms of immune escape, as they show that prostate cancer metastasis in the bone utilize TGF $\beta$ to restrain $\mathrm{T}_{\mathrm{H}} 1$ 
differentiation of $\mathrm{T}$ cells in order to escape from immune checkpoint therapy [18].

Although CTCs and sometimes even CTC clusters can be found in a large subset of patients, extracranial metastatic outgrowth are very rare in GBM [23, 24, 31, 39]. Interestingly, although to be expected in cases of peripheral metastatic outgrowth, we did not detect CTCs in this case, or a case of an IDH1 mutated anaplastic astrocytoma WHO ${ }^{\circ} \mathrm{III}[26]$. It is unclear whether the peripheral immunosuppression of intracranial GBM is insufficient to support extracranial growth of CTCs, or if the CTCs are unable to adapt to the non-CNS microenvironment or unable to establish a similarly suppressive microenvironment under the requirements of a peripheral "soil". Our observation of significantly reduced overall $\mathrm{CD}^{+} \mathrm{T}$ cell and more specific $\mathrm{CD} 8^{+}$cytotoxic T-cell infiltration in patients being positive for CTCs indicates a direct link between the tumourspecific immune response, and potentially also immunocompetence, and the occurrence of tumour cells in the circulation.

Even though not reaching the strict definition of a hypermutated genotype, defined by more than 10 mutations per mega base pair, the increased tumour mutational burden of the extracranial GBM metastasis presented in our case, might explain why multiple metastasis were able to form. Although a generally hypermutated phenotype was suggested to favor recognition by tumour-specific immune cells due to the presence of new tumour-specific antigens [10], tumour mutational burden in glioma does not seem follow the usual correlation of a better overall survival or response to checkpoint inhibition with higher mutational burden $[1,36]$. It is unclear why a higher mutational burden in glioma rather results in a worsened overall survival [36]. One hypothesis is, that hypermutated tumours decrease the recognizable antigen load below the threshold of effective tumour-specific activation $[1,27,49]$.

Another hypothesis favors the occurrence of immunological escape variants by increased prevalence of somatic mutations in the human leukocyte antigen (HLA) class I region [37]. The HLA class I molecules present tumour antigen peptides and complete loss might result in evasion from adaptive immune recognition [37, 48]. Interestingly, somatic mutations in the HLA class I locus were not observed in primary GBM and, although the tissue quality prohibited WGS coverage of the HLA region in the metastasis, we did also not observe mutations of the HLA locus in this case [37]. However, a study by Wang et al. revealed that $15 \%$ of recurrent GBM after radio- and chemotherapy with temozolomide presented with a hypermutated genotype [46]. The increased tumour mutational burden might result in additional mutations which might favor immunological escape. The comparably high mutational burden of the studied extracranial metastasis resulted in various somatic mutations in immunologically relevant sites. As described above, we found missense variant mutations in multiple genes, e.g. ANXA5, LGALS14 and FGL1, potentially affecting the tumour-specific immune response of the GBM metastasis. ANXA5, which also displayed a CNA loss, encodes the protein Annexin V, which is involved in stabilization of the $\mathrm{T}$ cell receptor (TCR) and peptide-MHC interactions during formation of an immunological synapse [25]. Galectin-14 (LGALS14) is expressed mainly by the placenta and was shown to be able to induce apoptosis of activated T lymphocytes [4]. The gene FGL1 encodes for a protein called fibrinogenlike protein 1 , which was recently described to be highly expressed in many cancers and to inhibit antigenspecific $\mathrm{T}$ cell activation through the interaction with the known checkpoint molecule Lag-3 [47]. Increased levels of FGL1 in serum was associated with increased resistance to anti-PD1 checkpoint inhibition [47]. Although the confirmation of pathophysiological mechanisms of each of these mutations and assessment of their relevance for immune escape extends the scope of this manuscript, the above described mutations might represent an interesting target for future studies of immune escape.

Taken together, the comprehensive molecular and immunological profiling of this unique case of extracranial GBM metastases gives new insights into potential mechanisms of immune escape of GBM. We postulate that the combination of functional impairment of the peripheral immune system, as reflected by a steady increase of exhaustion markers, such as KLRG1 and CD57, and the occurrence of a metastasis with an increased mutational burden, enabled the extracranial dissemination and disease progression while intracranial GBM could be controlled by checkpoint inhibition.

\section{Materials and methods \\ Clinical data}

Clinical data and images were analysed after confirmation of peripheral GBM metastasis by two pathologists. The patient signed an informed consent. This study was approved by the local ethics council of the Hamburg chamber for physicians and was performed in accordance with the Helsinki declaration of 1975.

\section{Histology and immunohistochemistry analysis}

Routine histological and immunohistochemical analysis (H\&E, GFAP, p53, PD-L1 (clone E1L3N, Cell Signaling), CD3 (clone SP7, Zytomed), CD8 (clone SPI6, DCS)) was performed on paraffin embedded sections using a microtome and automatic staining system (Ventana, Roche Diagnostics). 
PBMC isolation and multicolor flow-cytometry

Peripheral blood was collected into EDTA-containing tubes. Ficoll gradient (PromoCell) centrifugation was performed for the isolation of PBMCs. PBMCs were used after being frozen in RPMI/10\% DMSO. Flowcytometric analysis was performed on PBMCs using multicolor antibody staining as described previously [30]. In addition, immune subpopulations were determined using a TCR $\gamma \delta$-FITC (clone IMMU510, BeckmanCoulter, $\gamma \delta \mathrm{T}$ cells), CD14-PE (clone RMO52, BeckmanCoulter, monocytes), CD56-ECD (clone N901(NKH-1), BeckmanCoulter, NK cells), CD3-PC-5.5 (clone UCHT1, BeckmanCoulter), CD16-PC-7 (clone 3G8, BeckmanCoulter, monocytes), CD19-APC (clone J3-119, BeckmanCoulter, B cells), CD4-APC-Cy7 (clone RPA-T4, BioLegend), CD45-PacBlue (clone J33, BeckmanCoulter) and for another panel CD25-FITC (clone B1.49.9, BeckmanCoulter), CD3-PC-5.5 (clone UCHT1, BeckmanCoulter), CD8-PC-7 (clone SFCI2ITHY2D3, BeckmanCoulter), CD69-APC (clone FN50, BioLegend) and CD4-APC-Cy7 (clone RPA-T4, BioLegend). Briefly, after $\mathrm{F}_{\mathrm{C}}$-blocking, samples were stained in flowcytometry staining buffer (eBioscience) for $45 \mathrm{~min}$ at room temperature with the antibody cocktails, washed, and resuspended in buffer prior to analysis. Analysis was performed on a BD LSRFortessa flow-cytometer and using the FACSDiva software (Becton Dickinson).

\section{CTC / intratumoural immune cell correlation}

Formalin fixed paraffin embedded tissue part of an already published cohort in which the peripheral blood was tested for the presence of CTCs, [31] were stained for CD3 (clone SP7, Zytomed), CD8 (clone SPI6, DCS) and CD68 (clone PG-M1, Dako) using a Ventana (Roche Diagnostics). For each tumour, at least ten representative microscopic images were acquired. Images where then automatically quantified using the immuno-ratio plugin for the Fiji analysis software [42].

Whole exome sequencing and $850 \mathrm{~K}$ methylation profiling Genomic DNA from fresh frozen or paraffin-embedded tumour tissue or peripheral immune cells $\left(>1 \times 10^{6}\right.$ PBMCs) was isolated using the genomic DNA miniprep kit (innuPREP DNA Mini Kit, Analytic Jena AG). For tumour tissue representative tumour areas were identified from using light microscopy. If necessary, macrodissection was performed. For the metastatic tissue WGS, gDNA was amplified after isolation from paraffinembedded tissue using the PicoPLEX v2 kit (Takara Bio) as described before [3]. Whole genome sequencing was performed from tumour tissue gDNA using commercial services with the HiSeq X-Ten/PE150 platform using a $350 \mathrm{bp}$ short insert library (BGI Tech Solutions, Hong Kong, China). DNA extraction for methylation analysis was performed from paraffin-embedded tissue using a Maxwell system (Promega). Methylation analysis was performed using the Illumina Infinium MethylationEPIC BeadChip, according to protocols supplied by the manufacturer.

\section{Data analysis}

For whole genome sequencing data, structural variants were called with Manta (v1.6.0) [8]. Strelka (v2.9.10) was used for calling short variants [21]. Both programs were run with default parameters and indel candidates identified by Manta were provided to Strelka as suggested by the authors of the latter program. Variants not passing the tools internal filters were not considered for further analysis. The remaining variants were annotated with Ensembl Variant Predictor (VEP) (v98.2) [28]. Variants annotated with an allelic frequency above $10 \%$ in GnomAD were excluded. Other variants were kept if they were predicted to have an impact on protein level or if they had an entry in the COSMIC database (v89). CNA profiles were obtained using Control-FREEC [6] as described before [35]. TMB calculations from WGS data are based on genomic regions which are covered at least $8 \mathrm{x}$ in all samples. Methylation data was analysed using the online platform provided by www.molecularneuropathology.org [7]. Statistical analyses of the immunohistochemical stainings was performed with GraphPad Prism. Plots were graphed using GraphPad Prism, R Foundation's R v2.12, Adobe Illustrator CC 2018.

\section{Supplementary information}

Supplementary information accompanies this paper at https://doi.org/10 1186/s40478-020-00906-9.

Additional file 1. Supplemental Figure 1.

Additional file 2. Supplemental Table 1.

\section{Abbreviations}

CD: Cluster of differentiation; CD4: Conventional, non- reg, $_{\text {reg }} 4^{+}$T-cells; CNA: Copy number alterations; CNS: Central nervous system;

CTCs: Circulating tumour cells; DNA: Deoxyribonucleic acid; GBM: Glioblastoma; HLA: Human leukocyte antigen; IDH1: Isocitrate dehydrogenase 1; KLRG1: Killer cell lectin-like receptor subfamily G member 1; MGMT: O6-Methylguanin-DNA-Methyltransferase; NGS: Next-generation sequencing; PBL: Peripheral blood lymphocytes; PD-1: Programmed death-1; PD-L1: Programmed death ligand-1; $\mathrm{T}_{\mathrm{CM}}$ : central memory T-cell; TCR: T-cell receptor; $T_{E M}$ : Effector memory T-cell; $T_{H}$ : T-helper cell; TIL: Tumour-infiltrating lymphocytes; TMB: Tumour mutational burden; $T_{\mathrm{Nv}}$ : Naïve T-cell;

$\mathrm{T}_{\text {reg: }}$ : Regulatory T-cell, $\mathrm{CD}^{+} \mathrm{CD}^{+}{ }^{+} \mathrm{CD} 25^{\text {high }} \mathrm{CD} 127^{\text {low }} ; \mathrm{T}_{\mathrm{TE}}$ : Terminal effector T-cell; $\mathrm{T}_{\mathrm{TM}}$ : Transitional memory T-cell

\section{Acknowledgments}

This work was supported by grants from the Else Kröner-Fresenius Stiftung (to M.M.), the Anni Hofmann Stiftung (to K.L.) and the Johannes-Bauer Stiftung. U.S. is supported by the Fördergemeinschaft Kinderkrebs-Zentrum Hamburg. SJ and KP are funded by the ERC Advanced Investigator Grant INJURMET (Nr. 834974). We also thank our excellent technicians, Svenja Zapf, Katharina Kolbe, Mareike Holz and Sarah Matula, as well as the technicians from the FACS core facility who continuously supported us during flow cytometric measurements. 


\section{Authors' contributions}

MM collected the samples, performed the flow-cytometric analysis, analysed the data and prepared the manuscript. SS collected samples, analysed the data and supported preparing the manuscript. SJ, DB, MA analysed and interpreted the genomic data. JM performed the histopathological analysis and interpreted the manuscript. US performed the methylation analysis and interpreted the manuscript. TM gathered and interpreted the clinical data. KP and SR performed genomic DNA extraction from metastatic tissue, analysed the data and interpreted the manuscript. CM analysed the molecular data, prepared the manuscript and supervised the study. KL supplied funding, prepared the manuscript and provided scientific input. MW was responsible for the clinical course of the patient, supplied funding, supervised the study and prepared the manuscript. The authors read and approved the final manuscript.

\section{Funding}

No specific funding applicable.

\section{Availability of data and materials}

The datasets generated or analysed during the current study are not publicly available due to protection of individual privacy/genetic data protection, but are available after anonymisation from the corresponding author on reasonable request.

\section{Ethics approval and consent to participate}

The patient signed an informed consent. This study was approved by the local ethics council of the Hamburg chamber for physicians and was performed in accordance with the Helsinki declaration of 1975.

\section{Consent for publication}

The patient signed an informed consent.

\section{Competing interests}

The authors declare that they have no competing interests.

\begin{abstract}
Author details
'Department of Neurosurgery, University Medical Center Hamburg-Eppendorf, Martinistr. 52, 20246 Hamburg, Germany. ${ }^{2}$ Department of Oncology and Hematology, Bone Marrow Transplantation with Section Pneumology, Hubertus Wald University Cancer Center Hamburg, University Medical Centre Hamburg-Eppendorf, Hamburg, Germany. Institute of Tumor Biology, University Medical Center Hamburg-Eppendorf, Hamburg, Germany. ${ }^{4}$ Bioinformatics Core, University Medical Center Hamburg-Eppendorf, Hamburg, Germany. ${ }^{5}$ Institute of Neuropathology, University Medical Center Hamburg-Eppendorf, Hamburg, Germany. ${ }^{6}$ Department of Pediatric Hematology and Oncology, University Medical Center Hamburg-Eppendorf, Hamburg, Germany. ${ }^{7}$ Research Institute Children's Cancer Center Hamburg, Hamburg, Germany.
\end{abstract}

Received: 14 January 2020 Accepted: 29 February 2020

Published online: 09 March 2020

\section{References}

1. Ahmad H, Fadul CE, Schiff D, Purow B (2019) Checkpoint inhibitor failure in hypermutated and mismatch repair-mutated recurrent high-grade gliomas. Neurol Pract 6:424-427. https://doi.org/10.1093/nop/npz016

2. Apetoh L, Smyth MJ, Drake CG, Abastado J-P, Apte RN, Ayyoub M, Blay J-Y, Bonneville M, Butterfield LH, Caignard A, Castelli C, Cavallo F, Celis E, Chen L, Colombo MP, Comin-Anduix B, Coukos G, Dhodapkar MV, Dranoff G, Frazer IH, Fridman W-H, Gabrilovich DI, Gilboa E, Gnjatic S, Jäger D, Kalinski P, Kaufman HL, Kiessling R, Kirkwood J, Knuth A, Liblau R, Lotze MT, Lugli E, Marincola F, Melero I, Melief CJ, Mempel TR, Mittendorf EA, Odun K, Overwijk WW, Palucka AK, Parmiani G, Ribas A, Romero P, Schreiber RD, Schuler G, Srivastava PK, Tartour E, Valmori D, van der Burg SH, van der Bruggen P, van den Eynde BJ, Wang E, Zou W, Whiteside TL, Speiser DE, Pardoll DM, Restifo NP, Anderson AC (2015) Consensus nomenclature for CD8+ T cell phenotypes in cancer. Oncoimmunology 4:e998538. https://doi. org/10.1080/2162402X.2014.998538

3. Babayan A, Alawi M, Gormley M, Müller V, Wikman H, McMullin RP, Smirnov DA, Li W, Geffken M, Pantel K, Joosse SA (2017) Comparative study of whole genome amplification and next generation sequencing performance of single cancer cells. Oncotarget 8:56066-56080. https://doi.org/10.18632/ oncotarget.10701

4. Balogh A, Toth E, Romero R, Parej K, Csala D, Szenasi NL, Hajdu I, Juhasz K, Kovacs AF, Meiri H, Hupuczi P, Tarca AL, Hassan SS, Erez O, Zavodszky P, Matko J, Papp Z, Rossi SW, Hahn S, Pallinger E, Than NG (2019) Placental Galectins are key players in regulating the maternal adaptive immune response. Front Immunol 10:1240. https://doi.org/10.3389/fimmu.2019.01240

5. Bockmayr M, Klauschen F, Maire CL, Rutkowski S, Westphal M, Lamszus K, Schüller U, Mohme M (2019) Immunologic profiling of mutational and transcriptional subgroups in pediatric and adult high-grade Gliomas. Cancer Immunol Res. https://doi.org/10.1158/2326-6066.CIR-18-0939

6. Boeva V, Popova T, Bleakley K, Chiche P, Cappo J, Schleiermacher G, Janoueix-Lerosey I, Delattre O, Barillot E (2012) Control-FREEC: a tool for assessing copy number and allelic content using next-generation sequencing data. Bioinformatics 28:423-425. https://doi.org/10.1093/ bioinformatics/btr670

7. Capper D, Jones DTW, Sill M, Hovestadt V, Schrimpf D, Sturm D, Koelsche C, Sahm F, Chavez L, Reuss DE, Kratz A, Wefers AK, Huang K, Pajtler KW, Schweizer L, Stichel D, Olar A, Engel NW, Lindenberg K, Harter PN, Braczynski AK, Plate KH, Dohmen H, Garvalov BK, Coras R, Hölsken A, Hewer E, Bewerunge-Hudler M, Schick M, Fischer R, Beschorner R, Schittenhelm J, Staszewski O, Wani K, Varlet P, Pages M, Temming P, Lohmann D, Selt F, Witt H, Milde T, Witt O, Aronica E, Giangaspero F, Rushing E, Scheurlen W, Geisenberger C, Rodriguez FJ, Becker A, Preusser M, Haberler C, Bjerkvig R, Cryan J, Farrell M, Deckert M, Hench J, Frank S, Serrano J, Kannan K, Tsirigos A, Brück W, Hofer S, Brehmer S, Seiz-Rosenhagen M, Hänggi D, Hans V, Rozsnoki S, Hansford JR, Kohlhof P, Kristensen BW, Lechner M, Lopes B, Mawrin C, Ketter R, Kulozik A, Khatib Z, Heppner F, Koch A, Jouvet A, Keohane C, Mühleisen H, Mueller W, Pohl U, Prinz M, Benner A, Zapatka M, Gottardo NG, Driever PH, Kramm CM, Müller HL, Rutkowski S, von Hoff K, Frühwald MC, Gnekow A, Fleischhack G, Tippelt S, Calaminus G, Monoranu C-M, Perry A, Jones C, Jacques TS, Radlwimmer B, Gessi M, Pietsch T, Schramm J, Schackert G, Westphal M, Reifenberger G, Wesseling P, Weller M, Collins VP, Blümcke I, Bendszus M, Debus J, Huang A, Jabado N, Northcott PA, Paulus W, Gajjar A, Robinson GW, Taylor MD, Jaunmuktane Z, Ryzhova M, Platten M, Unterberg A, Wick W, Karajannis MA, Mittelbronn M, Acker T, Hartmann C, Aldape K, Schüller U, Buslei R, Lichter P, Kool M, Herold-Mende C, Ellison DW, Hasselblatt M, Snuderl M, Brandner S, Korshunov A, von Deimling A, Pfister SM (2018) DNA methylation-based classification of central nervous system tumours. Nature 555:469-474. https://doi.org/10.1038/nature26000

8. Chen X, Schulz-Trieglaff O, Shaw R, Barnes B, Schlesinger F, Källberg M, Cox AJ, Kruglyak S, Saunders CT (2016) Manta: rapid detection of structural variants and indels for germline and cancer sequencing applications. Bioinformatics 32:1220-1222. https://doi.org/10.1093/bioinformatics/btv710

9. Chongsathidkiet P, Jackson C, Koyama S, Loebel F, Cui X, Farber SH, Woroniecka K, Elsamadicy AA, Dechant CA, Kemeny HR, Sanchez-Perez L, Cheema TA, Souders NC, Herndon JE, Coumans J-V, Everitt JI, Nahed BV, Sampson JH, Gunn MD, Martuza RL, Dranoff G, Curry WT, Fecci PE (2018) Sequestration of T cells in bone marrow in the setting of glioblastoma and other intracranial tumors. Nat Med 24:1459-1468. https://doi.org/10.1038/s41591-018-0135-2

10. Ciombor KK, Goldberg RM (2018) Hypermutated tumors and immune checkpoint inhibition. Drugs 78:155-162. https://doi.org/10.1007/s40265018-0863-0

11. da Cunha MLV, Maldaun MVC (2019) Metastasis from glioblastoma multiforme: a meta-analysis. Rev Assoc Med Bras 65:424-433. https://doi. org/10.1590/1806-9282.65.3.424

12. Fonkem E, Lun M, Wong ET (2011) Rare phenomenon of extracranial metastasis of glioblastoma. J Clin Oncol 29:4594-4595. https://doi.org/10. 1200/JCO.2011.39.0187

13. Forbes SA, Beare D, Boutselakis H, Bamford S, Bindal N, Tate J, Cole CG, Ward S, Dawson E, Ponting L, Stefancsik R, Harsha B, Kok CY, Jia M, Jubb H, Sondka Z, Thompson S, De T, Campbell PJ (2017) COSMIC: somatic cancer genetics at high-resolution. Nucleic Acids Res 45:D777-D783. https://doi. org/10.1093/nar/gkw1121

14. Goodwin CR, Liang L, Abu-Bonsrah N, Hdeib A, Elder BD, Kosztowski T, Bettegowda C, Laterra J, Burger P, Sciubba DM (2016) Extraneural Glioblastoma Multiforme vertebral metastasis. World Neurosurg 89:578-582. e3. https://doi.org/10.1016/j.wneu.2015.11.061

15. Hamilton JD, Rapp M, Schneiderhan T, Marcel Schneiderhan T, Sabel M, Hayman A, Scherer A, Kröpil P, Budach W, Gerber P, Kretschmar U, Arne 
Gerber P, Prabhu S, Ginsberg LE, Bölke E, Matuschek C (2014) Glioblastoma multiforme metastasis outside the CNS: three case reports and possible mechanisms of escape. J Clin Oncol 32:e80-e84. https://doi.org/10.1200/ JCO.2013.48.7546

16. Hanahan D, Weinberg R a (2011) Hallmarks of cancer: the next generation. Cell 144:646-674. https://doi.org/10.1016/j.cell.2011.02.013

17. Hoffman HA, Li CH, Everson RG, Strunck JL, Yong WH, Lu DC (2017) Primary lung metastasis of glioblastoma multiforme with epidural spinal metastasis: case report. J Clin Neurosci 41:97-99. https://doi.org/10.1016/j.jocn.2017.03. 033

18. Jiao S, Subudhi SK, Aparicio A, Ge Z, Guan B, Miura Y, Sharma P (2019) Differences in tumor microenvironment dictate $T$ helper lineage polarization and response to immune checkpoint therapy. Cell 179:1177-1190.e13. https://doi.org/10.1016/j.cell.2019.10.029

19. Jimsheleishvili S, Alshareef AT, Papadimitriou K, Bregy A, Shah AH, Graham RM, Ferraro N, Komotar RJ (2014) Extracranial glioblastoma in transplant recipients. J Cancer Res Clin Oncol 140:801-807. https://doi.org/10.1007/ s00432-014-1625-3

20. Kalokhe G, Grimm SA, Chandler JP, Helenowski I, Rademaker A, Raizer JJ (2012) Metastatic glioblastoma: case presentations and a review of the literature. J Neuro-Oncol 107:21-27. https://doi.org/10.1007/s11060-0110731-1

21. Kim S, Scheffler K, Halpern AL, Bekritsky MA, Noh E, Källberg M, Chen X, Kim Y, Beyter D, Krusche P, Saunders CT (2018) Strelka2: fast and accurate calling of germline and somatic variants. Nat Methods 15:591-594. https:/doi.org/ 10.1038/s41592-018-0051-x

22. Koyama S, Akbay EA, Li YY, Herter-Sprie GS, Buczkowski KA, Richards WG, Gandhi L, Redig AJ, Rodig SJ, Asahina H, Jones RE, Kulkarni MM, Kuraguchi M, Palakurthi S, Fecci PE, Johnson BE, Janne PA, Engelman JA, Gangadharan SP, Costa DB, Freeman GJ, Bueno R, Hodi FS, Dranoff G, Wong K-K, Hammerman PS (2016) Adaptive resistance to therapeutic PD-1 blockade is associated with upregulation of alternative immune checkpoints. Nat Commun 7:10501. https://doi.org/10.1038/ncomms10501

23. Krol I, Castro-Giner F, Maurer M, Gkountela S, Szczerba BM, Scherrer R, Coleman N, Carreira S, Bachmann F, Anderson S, Engelhardt M, Lane H, Evans TRJ, Plummer R, Kristeleit R, Lopez J, Aceto N (2018) Detection of circulating tumour cell clusters in human glioblastoma. Br J Cancer 119: 487-491. https://doi.org/10.1038/s41416-018-0186-7

24. Macarthur KM, Kao GD, Chandrasekaran S, Alonso-Basanta M, Chapman C, Lustig R a, Wileyto EP, Hahn SM, Dorsey JF (2014) Detection of brain tumor cells in the peripheral blood by a telomerase promoter-based assay. Cancer Res 74:2152-2159. https://doi.org/10.1158/0008-5472.CAN-13-0813

25. Mao C-P, Peng S, Yang A, He L, Tsai Y-C, Hung C-F, Wu T-C (2018) Programmed self-assembly of peptide-major histocompatibility complex for antigen-specific immune modulation. Proc Natl Acad Sci U S A 115:E4032E4040. https://doi.org/10.1073/pnas.1718434115

26. Martens T, Matschke J, Müller C, Riethdorf S, Balabanov S, Westphal M, Heese O (2013) Skeletal spread of an anaplastic astrocytoma (WHO grade III) and preservation of histopathological properties within metastases. Clin Neurol Neurosurg 115:323-328. https://doi.org/10.1016/j.clineuro.2012.05.025

27. McGranahan N, Furness AJS, Rosenthal R, Ramskov S, Lyngaa R, Saini SK, Jamal-Hanjani M, Wilson GA, Birkbak NJ, Hiley CT, Watkins TBK, Shafi S, Murugaesu N, Mitter R, Akarca AU, Linares J, Marafioti T, Henry JY, Van Allen EM, Miao D, Schilling B, Schadendorf D, Garraway LA, Makarov V, Rizvi NA, Snyder A, Hellmann MD, Merghoub T, Wolchok JD, Shukla SA, Wu CJ, Peggs KS, Chan TA, Hadrup SR, Quezada SA, Swanton C (2016) Clonal neoantigens elicit T cell immunoreactivity and sensitivity to immune checkpoint blockade. Science 351:1463-1469. https://doi.org/10.1126/science.aaf1490

28. McLaren W, Gil L, Hunt SE, Riat HS, Ritchie GRS, Thormann A, Flicek P, Cunningham F (2016) The Ensembl variant effect predictor. Genome Biol 17: 122. https://doi.org/10.1186/s13059-016-0974-4

29. Mohme M, Riethdorf S, Pantel K (2016) Circulating and disseminated tumour cells - mechanisms of immune surveillance and escape. Nat Rev Clin Oncol 14(3):155. https://doi.org/10.1038/nrclinonc.2016.144

30. Mohme M, Schliffke S, Maire CL, Rünger A, Glau L, Mende KC, Matschke J, Gehbauer C, Akyüz N, Zapf S, Holz M, Schaper M, Martens T, Schmidt NO, Peine S, Westphal M, Binder M, Tolosa E, Lamszus K (2018) Immunophenotyping of newly diagnosed and recurrent Glioblastoma defines distinct immune exhaustion profiles in peripheral and tumorinfiltrating lymphocytes. Clin Cancer Res 24(17):4187. https://doi.org/10. 1158/1078-0432.CCR-17-2617
31. Muller C, Holtschmidt J, Auer M, Heitzer E, Lamszus K, Schulte A, Matschke J, Langer-Freitag S, Gasch C, Stoupiec M, Mauermann O, Peine S, Glatzel M, Speicher MR, Geigl JB, Westphal M, Pantel K, Riethdorf S (2014) Hematogenous dissemination of glioblastoma multiforme. Sci Transl Med 6: 247ra101. https://doi.org/10.1126/scitranslmed.3009095

32. Pasquier B, Pasquier D, N'Golet A, Panh MH, Couderc P (1980) Extraneural metastases of astrocytomas and glioblastomas: clinicopathological study of two cases and review of literature. Cancer 45:112-125. https://doi.org/10. 1002/1097-0142(19800101)45:1<112::aid-cncr2820450121>3.0.co;2-9

33. Reardon DA, Omuro A, Brandes AA, Rieger J, Wick A, Sepulveda J, Phuphanich S, de Souza P, Ahluwalia MS, Lim M, Vlahovic G, Sampson J (2017) OS10.3 randomized phase 3 study evaluating the efficacy and safety of Nivolumab vs Bevacizumab in patients with recurrent Glioblastoma: CheckMate 143. Neuro-Oncology 19:iii21. https://doi.org/10.1093/neuonc/ nox036.071

34. Rennert RC, Hoshide RR, Signorelli JW, Amaro D, Sack JA, Brennan CW, Chen CC (2017) Concurrence of chromosome 6 chromothripsis and glioblastoma metastasis. J Neurosurg 126:1472-1478. https://doi.org/10.3171/2016.4. JNS153052

35. Riebensahm C, Joosse SA, Mohme M, Hanssen A, Matschke J, Goy Y, Witzel I, Lamszus K, Kropidlowski J, Petersen C, Kolb-Kokocinski A, Sauer S, Borgmann K, Glatzel M, Müller V, Westphal M, Riethdorf S, Pantel K, Wikman H (2019) Clonality of circulating tumor cells in breast cancer brain metastasis patients. Breast Cancer Res 21:101. https://doi.org/10.1186/ s13058-019-1184-2

36. Samstein RM, Lee C-H, Shoushtari AN, Hellmann MD, Shen R, Janjigian YY, Barron DA, Zehir A, Jordan EJ, Omuro A, Kaley TJ, Kendall SM, Motzer RJ, Hakimi AA, Voss MH, Russo P, Rosenberg J, lyer G, Bochner BH, Bajorin DF, Al-Ahmadie HA, Chaft JE, Rudin CM, Riely GJ, Baxi S, Ho AL, Wong RJ, Pfister DG, Wolchok JD, Barker CA, Gutin PH, Brennan CW, Tabar V, Mellinghoff IK, DeAngelis LM, Ariyan CE, Lee N, Tap WD, Gounder MM, D'Angelo SP, Saltz L, Stadler ZK, Scher HI, Baselga J, Razavi P, Klebanoff CA, Yaeger R, Segal NH, Ku GY, DeMatteo RP, Ladanyi M, Rizvi NA, Berger MF, Riaz N, Solit DB, Chan TA, Morris LGT (2019) Tumor mutational load predicts survival after immunotherapy across multiple cancer types. Nat Genet 51:202-206. https://doi.org/10.1038/s41588-018-0312-8

37. Shukla SA, Rooney MS, Rajasagi M, Tiao G, Dixon PM, Lawrence MS, Stevens J, Lane WJ, Dellagatta JL, Steelman S, Sougnez C, Cibulskis K, Kiezun A, Hacohen N, Brusic V, Wu CJ, Getz G (2015) Comprehensive analysis of cancer-associated somatic mutations in class I HLA genes. Nat Biotechnol 33:1152-1158. https://doi.org/10.1038/nbt.3344

38. Steinfeld H, Cho MT, Retterer K, Person R, Schaefer GB, Danylchuk N, Malik S, Wechsler SB, Wheeler PG, van Gassen KLI, Terhal PA, Verhoeven VJM, van Slegtenhorst MA, Monaghan KG, Henderson LB, Chung WK (2016) Mutations in HIVEP2 are associated with developmental delay, intellectual disability, and dysmorphic features. Neurogenetics 17:159-164. https://doi. org/10.1007/s10048-016-0479-z

39. Sullivan JP, Nahed BV, Madden MW, Oliveira SM, Springer S, Bhere D, Chia S, Wakimoto H, Rothenberg SM, Sequist LV, Kapur R, Shah K, lafratea J, Curry WT, Loeffler JS, Batchelor TT, Louis DN, Toner M, Maheswaran S, Haber DA (2014) Brain tumor cells in circulation are enriched for Mesenchymal gene expression. Cancer Discov 4(11):1299. https://doi.org/10.1158/2159-8290.CD14-0471

40. Sun L, Chen X, Jin X, Huang Q, Wang W, Zhi D, Chen D (2014) Identification and characterization of human MIBP1 gene in glioma cell differentiation. J Mol Neurosci 52:294-301. https://doi.org/10.1007/s12031-013-0144-z

41. Swinnen J, Gelin G, Fransis S, Vandevenne J, Van Cauter S (2019) Glioblastoma with extracranial parotid, lymph node, and pulmonary metastases: a case report. Radiol Case Rep 14:1334-1347. https://doi.org/10. 1016/j.radcr.2019.08.011

42. Tuominen VJ, Ruotoistenmäki S, Viitanen A, Jumppanen M, Isola J (2010) ImmunoRatio: a publicly available web application for quantitative image analysis of estrogen receptor (ER), progesterone receptor (PR), and Ki-67. Breast Cancer Res 12:R56. https://doi.org/10.1186/bcr2615

43. Ueda R, Fujita M, Zhu X, Sasaki K, Kastenhuber ER, Kohanbash G, McDonald $\mathrm{H}$ a, Harper J, Lonning S, Okada H (2009) Systemic inhibition of transforming growth factor-beta in glioma-bearing mice improves the therapeutic efficacy of glioma-associated antigen peptide vaccines. Clin Cancer Res 15:6551-6559. https://doi.org/10.1158/1078-0432.CCR-09-1067

44. Ueda S, Mineta T, Suzuyama K, Furuta M, Shiraishi T, Tabuchi K (2003) Biologic characterization of a secondary glioblastoma with extracranial 
progression and systemic metastasis. Neuro-Oncology 5:14-18. https://doi. org/10.1093/neuonc/5.1.14

45. Umphlett M, Shea S, Tome-Garcia J, Zhang Y, Hormigo A, Fowkes M,

Tsankova NM, Yong RL (2020) Widely metastatic glioblastoma with BRCA1 and ARID1A mutations: a case report. BMC Cancer 20:47. https://doi.org/10. 1186/s12885-020-6540-1

46. Wang J, Cazzato E, Ladewig E, Frattini V, Rosenbloom DIS, Zairis S, Abate F, Liu Z, Elliott O, Shin Y-J, Lee J-K, Lee I-H, Park W-Y, Eoli M, Blumberg AJ, Lasorella A, Nam D-H, Finocchiaro G, lavarone A, Rabadan R (2016) Clonal evolution of glioblastoma under therapy. Nat Genet 48:768-776. https://doi. org/10.1038/ng.3590

47. Wang J, Sanmamed MF, Datar I, Su TT, Ji L, Sun J, Chen L, Chen Y, Zhu G, Yin W, Zheng L, Zhou T, Badri T, Yao S, Zhu S, Boto A, Sznol M, Melero I, Vignali DAA, Schalper K, Chen L (2019) Fibrinogen-like protein 1 is a major immune inhibitory ligand of LAG-3. Cell 176:334-347.e12. https://doi.org/10. 1016/j.cell.2018.11.010

48. Yeung JT, Hamilton RL, Ohnishi K, Ikeura M, Potter DM, Nikiforova MN, Ferrone S, Jakacki RI, Pollack IF, Okada H (2013) LOH in the HLA class I region at 6p21 is associated with shorter survival in newly diagnosed adult glioblastoma. Clin Cancer Res 19:1816-1826. https://doi.org/10.1158/10780432.CCR-12-2861

49. Zappasodi R, Merghoub T, Wolchok JD (2018) Emerging concepts for immune checkpoint blockade-based combination therapies. Cancer Cell 33: 581-598. https://doi.org/10.1016/j.ccell.2018.03.005

\section{Publisher's Note}

Springer Nature remains neutral with regard to jurisdictional claims in published maps and institutional affiliations.

Ready to submit your research? Choose BMC and benefit from:

- fast, convenient online submission

- thorough peer review by experienced researchers in your field

- rapid publication on acceptance

- support for research data, including large and complex data types

- gold Open Access which fosters wider collaboration and increased citations

- maximum visibility for your research: over $100 \mathrm{M}$ website views per year

At $\mathrm{BMC}$, research is always in progress.

Learn more biomedcentral.com/submissions 